\title{
Kurumsal Yönetim İlkelerine Uyum Derecelendirmesi: Borsa İstanbul Kurumsal Yönetim Endeksine (BIST-XKURY) Tabi Şirketler Üzerine Bir Analiz \\ (Compliance Rating of Corporate Governance Principles: An Analysis on Companies Based on Borsa Istanbul Corporate Governance Index (BIST-XKURY))
}

\section{Cengiz GÜNEY iD a}

a Kocaeli Üniversitesi, Gazanfer Bilge Meslek Yüksekokulu, Muhasebe ve Vergi Bölümü, Kocaeli, Türkiye. cengiz.guney@kocaeli.edu.tr

MAKALE BİLGísi
Anahtar Kelimeler:
Borsa İstanbul Kurumsal
Yönetim Endeksi (BIST-
XKURY)
Kurumsal Yönetim Uyum
Derecelendirmesi
Regresyon Analizi
Gönderilme Tarihi 5 Şubat
2020
Revizyon Tarihi 15 Nisan
2020
Kabul Tarihi 5 Mayıs 2020

Makale Kategorisi: Araştırma Makalesi

\section{ÖZET}

Amaç - Bu çalışmanın amacı; şirketlerin Kurumsal Yönetim İlkelerine Uyum Düzeyi unsurlarının Kurumsal Yönetim puanın oluşumundaki yordama etkisini belirlemektir. Ayrıca derecelendirme şirketine göre puan ortalamaları açısından farklıılı olup olmadığını tespit etmek çalışmanın diğer bir amacını oluşturmaktadır.

Yöntem - Araştırma çok değişkenli regresyon analizi yöntemiyle gerçekleştirilmiştir. Amaç çerçevesinde Borsa İstanbul Kurumsal Yönetim Endeksinde (BIST-XKURY) yer alan; 01.07.2019 tarihi itibari ile 47 adet olan şirketlerin Kurumsal Yönetim İlkelerine Uyum Derecelendirme puan verileri analiz kapsamında incelenmiştir. Araştırma modelinde Kurumsal Yönetim Derecelendirme Puanı bağımlı değişken iken, Pay Sahipleri Derecelendirme Puanı, Kamuyu Aydınlatma ve Şeffaflık Derecelendirme Puanı, Menfaat Sahipleri Derecelendirme Puanı, Yönetim Kurulu Derecelendirme Puanı bağımsız değişkenleri temsil etmektedir. Çoklu regresyon analizi yapılırken metot olarak "Enter" metodu seçilmiştir.

Bulgular - Çalışma sonucunda; Kurumsal Yönetim İlkeleri unsurların Kurumsal Yönetim puanının oluşumundaki göreli önem sırası Pay sahipleri Puanı, Yönetim Kurulu Puanı, Kamuyu Aydınlatma Ve Şeffaflık Puanı, Menfaat Sahipleri Puanı şeklinde olduğu tespit edilmiştir. Derecelendirme şirketleri açısından yapılan farklılık analizi sonucuna göre; Yönetim Kurulu puanı dışındaki tüm derecelendirme puanlarının derecelendirme şirketine göre farklılık göstermediği tespit edilmiştir. ( JCR: 8,9327 SAHA: 9,2025 KOBİRATE: 9,2254).

Tartışma - Araştırma bulguları sonucuna göre; Yönetim Kurulu derecelendirme puanında görülen sapma dışında önem sıralaması SPK (Sermaye Piyasası Kurulu) tarafından belirlenen etki düzeylerine paralel olarak şekillenmiştir. Ayrıca JCR derecelendirme şirketinin Yönetim Kurulu puanları diğer iki derecelendirme şirketine ait puanlardan istatistiksel açıdan anlamlı şekilde farklılaşttğ görülmüştür.

\begin{tabular}{l}
\hline ARTICLE INFO \\
\hline Keywords: \\
Borsa Istanbul Corporate \\
Governance Index (BIST- \\
XKURY) \\
Corporate Governance \\
Degree \\
Regression Analysis
\end{tabular}

Received 5 February 2020

Revised 15 April 2020

Accepted 5 May 2020

\section{ABSTRACT}

Purpose - The purpose of this study is; to determine the effect of the Corporate Governance Compliance Level elements on the predictive effect of the Corporate Governance score. In addition, to determine whether there is a difference in the average of points according to the rating company is another purpose of the study.

Design/methodology/approach - The research was carried out with multivariate regression analysis method. The data of 47 companies in the Borsa İstanbul Corporate Governance Index (BIST-XKURY); as of 01.07.2019, were analyzed within the scope of the analysis. In the research model, while Corporate Governance Rating Score is dependent variable, Shareholders Rating Score, Public Disclosure and Transparency Rating Score, Stakeholder Rating Score, and Board Rating Score represent independent variables. While performing multiple regression analysis, "Enter" method was chosen as the method.

Findings - In the results of study; the relative importance order of the Corporate Governance Principles in the formation of the Corporate Governance score was determined as Shareholders Score, Board of Directors Score, Public Disclosure and Transparency Score, Stakeholder Score. According to the results of the difference analysis made for the rating companies; It has been determined that all ratings except for the Board of Directors do not differ according to the rating company (JCR: 8,9327 SAHA: 9,2025 KOBIRATE: 9,2254).

Article Classification:

Research Article

Discussion - Except for the deviation in the Board's rating, the importance ranking was shaped in parallel with the impact levels determined by the SPK. It was observed that the scores of the Board of Directors of the JCR rating company differed significantly from the scores of the other two rating companies.

\section{Önerilen Atıf/ Suggested Citation}

Güney, C. (2020) Kurumsal Yönetim İlkelerine Uyum Derecelendirmesi: Borsa İstanbul Kurumsal Yönetim Endeksine (BIST-XKURY) Tabi Şirketler Üzerine Bir Analiz, İşletme Araştırmaları Dergisi, 12 (2), 1297-1307. 


\section{GİRIŞ}

“Kurum” Türk Dil Kurumunca "Evlilik, aile, ortaklık, mülkiyet gibi köklü bir yapıyı içeren, genellikle devletle ilişkisi olan yapı veya birlik, müessese" olarak tanımlanmıştır. "Kurumsallık" ise yine Türk Dil Kurumunca "Değişik birim ve fonksiyonlarıyla bir kurumun niteliklerine tam anlamiyla sahip olan." şeklinde tanımlanmıştır. "Yönetim" Türk Dil Kurumunca "Yönetme işi, çekip çevirme, idare" olarak tanımlanmıştır.

İşletme Bilimi açısından kavramlar ele alındığında ise "Kurum"; "Farklı amaçlara ulaşmak için bireyler tarafından şekillendirilen organize kuruluş, müessese, tesis" olarak tanımlanmaktadır. "Kurum" tanımının "davranışsal normların belirleyicisi olması; yasal bir çerçeveye sahip olması ve aktörlerden bağımsız olması; tüm topluma olduğu kadar küçük bir grup içinde uygulanabilir olması" şeklinde üç temel unsuru bulunmaktadır (Tutar, 2013:45). Kurumsallaşma ise "Örgütün üyelerinden bağımsız bir kimlik kazanması ve sosyal ihtiyaç ve baskıların doğal ürünü olarak duyarlı ve esnek bir organizma haline gelmesi” şeklinde tanımlanmaktadır. Kurumsallaşma ile kurumun faaliyetlerini devam ettirmesinde çalışanların kendi kişisel yöntemlerine bağlı olmadan, kurumun yöntemlerini üretmesi ve çalışanların kurumdan ayrılsa dahi işlerin aksamadan yürütülmesi ve kurumun sürekliliğinin sağlanması mümkün olmaktadır (Tutar, 2013:47). Kurumsallaşma üç aşamada gerçekleşmektedir. Birinci aşama örgütlerin yasalar, Pazar ve teknolojideki değişimlere göre geliştirdiği kalıplaşmış davranışlara dönüştüğü "alışma" aşamasıdır. İkinci aşama kalıplaşmaya başlayan davranışlar üzerinde herkesçe kabul gören anlamların oluştuğu "nesnelleşme" aşamasıdır. Son aşama ise davranışların dışsallık kazanarak kendi başlarına bir geçerlilik elde ettikleri "durulma" aşamasıdır (Tutar, 2013:407). "Kurumsal Yönetim" kavramı ise ülkelerin yasal bağlamları doğrultusunda farklı şekilde tanımlanmaktadır. OECD'ye göre kurumsal yönetim; bir şirketin tarafları arasındaki sorumluluk ve hak dağıtımını şekillendirmekte ve şirketin ileriye yönelik belirlemiş olduğu stratejik amaçları ve hedefleri için karar alıcılar ile ilgili kuralları tespit etmektedir (Kayalı ve Doğan, 2018:113). Kurumsal yönetimin dayandığı genel kabul görmüş 4 temel ilkeden söz etmek gerekmektedir. Bu ilkeler adil davranma, şeffaflık, hesap verebilirlik ve sorumluluktur (Tutar, 2013:349).

Adillik kavramı; yönetimin faaliyetlerini gerçekleştirirken pay ve menfaat sahiplerinin haklarını gözetmesi ve eşitlik ilkesi çerçevesinde hareket etmesi anlamına gelmektedir (Öztürk v.d. 2014:14). Yönetim kurulu üyelerinin ve şirket yöneticilerinin maddi çıkar doğuran faaliyetleri ve şirketi etkileyen işlemleri şeffaflık ve adillik ilkesi çerçevesinde kamuoyuna ve hissedarlara açıklanmalıdır (Aktan ve Vural, 2007:18).

Şeffaflık kavramı; işletme faaliyetlerinin etkilerinin işletme raporları ile izlenebilir olması ve raporlarda faaliyetlere ilişkin tüm bilinmesi gereken şeylerin şeffaf bir şekilde ortaya konması anlamına gelmektedir (Aras, 2007: 27). Şeffaflık kavramı gereği; işletmenin mali durumu, performansı, mülkiyeti ve kurumun yönetimi dahil, işletme ile ilgili tüm maddi konularda doğru ve zamanında açıklama yapılması gerekmektedir (Aktan ve Vural, 2007:17).

Hesap verebilirlik kavramı; işletme tarafından gerçekleştirilen faaliyetlerin etkilerinin, işletme dışı paydaşlara raporlanması anlamina gelmektedir (Aras, 2007:26). Planlama, hesap verme, denetleme ve raporlama, yerleştirme ve paydaşları konuya dahil etme aşamaları hesap verebilirlik kavramının aşamalarını oluşmaktadır (Aktan ve Vural, 2007:17).

Sorumluluk kavramı ise işletmenin tüm paydaşlarının haklarını yasalarda ve ikili anlaşmalarda öngörüldüğü şeklide tanımak durumunda olduğunu belirtmektedir (Tutar, 2013:350). Küresel rekabet ortamında işletmelerin ayakta kalması ve büyümesi için kurumsallaşmasını tamamlaması, hem sistem oluşturma hem de sistemin iyileştirilmesi için önem arz etmektedir.

Çalışma Giriş ve Sonuç bölümleri dışında "Kurumsal Yönetim İlkeleri Uyum Derecelendirmesi”, "Literatür" Ve "Araştırma" bölümü olmak üzere üç bölümden oluşmaktadır.

Çalışmanın birinci bölümü olan "Kurumsal Yönetim İlkeleri Uyum Derecelendirmesi", kısmında kurumsal yönetim ilkeleri ve derecelendirmeleri ile ilgili "Kurumsal Yönetim İlkelerinin Belirlenmesine Ve Uygulanmasına İlişkin Tebliğ" çerçevesinde bilgilere yer verilmiştir.

Çalışmanın ikinci bölümü olan "Literatür", kısmında Türkiye' de Borsa İstanbul Kurumsal yönetim endeksine tabi şirketler üzerinde yapılan çalışmalar incelenmiş, konunun eksik kalan yönleri anlaşılmaya çalışılmıştır. Yapılacak olan araştırma modeli için ön bilinç oluşturulmaya çalışılmıştır. 
Çalışmanın üçüncü bölümü olan "Araştırma" kısmında; araştırmanın amacı, kapsamı ve sınırlılıkları, yöntemi, üzerinde durulmuş; araştırma bulguları tablolar aracıllı̆g ile kaleme alınmıştır

\section{KURUMSAL YÖNETIM İLKELERİ UYUM DERECELENDİRMESİ}

Kurumsal yönetim ilkelerine uygun bir şekilde işletmelerin yönetilmesi sağlamak başta bilgi kullanıcıları için geniş kapsamda ise toplum için önem arz etmektedir. Borsa İstanbul da faaliyet gösteren işletmeler çeşitli endeksler tarafından izlenmekte ve derecelendirilmektedir. İşletmeler çeşitli kriterleri sağladıklarında Kurumsal Yönetim Endeksi (BIST-XKURY) ne girebilmektedir. Kurumsal Yönetim Endeksine tabi işletmeler belirli dönemlerde Kurumsal Yönetim açısından puanlanmaktadır. İlgili puanlama kredi ve derecelendirme şirketleri tarafından gerçekleştirilmektedir. Saha, Kobirate, JCR bu derecelendirme şirketlerine örnek olarak gösterilebilir.

Sermaye Piyasası Kurulu (SPK), “Kurumsal Yönetim İlkelerinin Belirlenmesine Ve Uygulanmasına İlişkin Tebliğ" ile Kurumsal Yönetim Endeksine tabi şirketlerin Kurumsal Yönetim İlkelerini Belirlemesi ve uygulamasına ilişkin esasları belirlemiştir. Bu esaslara göre Kurumsal Yönetimin çerçevesi pay sahipleri, kamuyu aydınlatma ve şeffaflık, menfaat sahipleri ve yönetim kurulu boyutları ile çizilmiştir. Pay sahipleri alt boyutu itibari ile; Pay Sahipliği, Haklarının Kullanımının Kolaylaştırılması, Bilgi Alma ve İnceleme Hakkı, Genel Kurula Katılım Hakkı, Oy Hakkı, Azlık Hakları, Kar Payı Hakkı, Payların Devri konuları ele alınmış ve bu alt başlıklara ilişkin esaslar belirlenmiştir. Kamuyu Aydınlatma ve Şeffaflık alt boyutu itibari ile Kamuyu Aydınlatma Esasları ve Araçları, İnternet Sitesi ve Faaliyet Raporu konuları ele alınmış ve bu alt başlıklara ilişkin esaslar belirlenmiştir. Menfaat Sahipleri alt boyutu itibari ile; Menfaat Sahiplerine İlişkin Şirket Politikası, Menfaat Sahiplerinin Şirket Yönetimine Katılımının Desteklenmesi, Şirketin İnsan Kaynakları Politikası, Müşteriler ve Tedarikçilerle İlişkiler, Etik Kurallar ve Sosyal Sorumluluk konuları ele alınmış ve bu alt başlıklara ilişkin esaslar belirlenmiştir. Yönetim Kurulu alt boyutunda ise Yönetim Kurulunun İşlevi, Yönetim Kurulunun Faaliyet Esasları, Yönetim Kurulunun Yapısı, Yönetim Kurulu Toplantılarının Şekli, Yönetim Kurulu Bünyesinde Oluşturulan Komiteler, Yönetim Kurulu Üyelerine ve Üst Düzey Yöneticilere Sağlanan Mali Haklar konuları ele alınmış ve bu alt başlıklara ilişkin esaslar belirlenmiştir.

Kurumsal Yönetim Derecelendirme Puanı; kurumsal yönetim boyutları puanı ve genel olarak kurumsal yönetim puanı hesaplaması şeklinde belirlenmektedir. Saha Derecelendirme şirketi Kurumsal Yönetim Derecelendirme Puanı; kurumların hissedar haklarına verdikleri önemin, kamuyu aydınlatma faaliyetlerinin, menfaat sahipleri ile ilişkilerinin ve yönetim kurullarının genel kredibilitesi hakkında bir görüş olarak tanımlamaktadır. Kurumsal yönetim derecelendirme puanı 1 ile 10 arasında verilir (1: En Zayıf - 10: En Güçlü).SPK Kurumsal Yönetim İlkelerine tam uyum gösteren şirketler 10 puan alır. Kurumsal Yönetim İlkelerine Uyum Puanlaması hesaplanırken SPK Kurumsal Yönetim İlkeleri'ne paralel olarak aşağıdaki ağırlıklar kullanılır: Pay Sahipleri ile Kamuyu Aydınlatma ve Şeffaflık boyutu \%25 oranında; Menfaat Sahipleri boyutu \%15 oranında; Yönetim Kurulu boyutu ise \%35 oranında Kurumsal Yönetim İlkelerine Uyum Puanlaması hesaplanırken hesaplamaya dahil edilmektedir. Saha Derecelendirme şirketine göre derecelendirme puanlarının anlamı şöyledir (http://www.saharating.com/ , Erişim: 03.01.2020):

- $\quad 9$ - 10: Şirketin SPK Kurumsal Yönetim İlkelerine önemli ölçüde uyduğu, yönetim ve iç kontrol mekanizmasının etkin olduğu, kurumsal yönetim risklerinin aktif şekilde yönetildiği, pay sahiplerinin haklarının gözetildiği, kamuyu aydınlatma şeffaflı̆̆ın en üst düzeyde olduğu anlamına gelmektedir.

- $\quad 7$ - 8: Şirketin SPK Kurumsal Yönetim İlkelerine önemli ölçüde uyduğu, yönetim ve iç kontrol mekanizmasının etkin bir şekilde işlediği ancak iyileştirmelere ihtiyacı olduğu, kurumsal yönetim risklerinin aktif şekilde yönetildiği, pay sahiplerinin haklarının gözetildiği, kamuyu aydınlatma şeffaflığın en üst düzeyde olduğu, ancak yine de çeşitli iyileştirmelere ihtiyacı olduğu anlamına gelmektedir

- $\quad$ 6: Şirketin SPK Kurumsal Yönetim İlkelerine orta derecede uyduğu, iç kontrol mekanizmasının orta derecede etkin olduğu, tespit edilen kurumsal risklerin aktif şekilde yönetildiği, uluslar arası standartlara uyum sağlama noktasında eksiklikleri olsa da ulusal standartlara uyum sağladığı, pay sahipleri; menfaat sahipleri; kamuyu aydınlatma ve şeffaflık ve yönetim kurulu alanlarının bazılarında iyileştirmelere ihtiyaç duyduğu anlamına gelmektedir. 
- $\quad 4-5$ : Şirketin SPK Kurumsal Yönetim İlkelerine asgari derecede uyduğu, iç kontrol mekanizmasının asgari düzeyde işlediği, kurumsal yönetim risklerinin tespitinde ve yönetilmesinde problemlerin olduğu, pay ve menfaat sahipleri ile kamuyu aydınlatma ve şeffaflık ve de yönetim kurulu alanlarının hemen hemen hepsinde önemli iyileştirmelere ihtiyaç duyduğu anlamına gelmektedir.

- $\quad<4$ : Şirketin SPK Kurumsal Yönetim İlkelerine uymadığı, tespit edilmeyen ve yönetilmeyen önemli kurumsal risklerinin olduğu, pay ve menfaat sahipleri ile kamuyu aydınlatma ve şeffaflık ve de yönetim kurulu alanlarının tamamında önemli iyileştirmelere ihtiyaç duyduğu anlamına gelmektedir. Böyle bir ortamda yatırımcı güveni en alt düzeydedir ve şirketin maddi zararlarla karşılaşma olasıllı̆ı yüksek seviyededir.

Çalışmanın bundan sonraki bölümünde Borsa İstanbul, Kurumsal Yönetim Endeksi (BIST-XKURY)' ne tabi işletmeler hakkında yapılmış çalışmalara yer verilecektir.

\section{LITERATÜR}

Türkiye'de Borsa İstanbul Kurumsal yönetim endeksine tabi şirketler üzerinde yapılan çalışmalar incelendiğinde çalışmaların daha çok Kurumsal Yönetim Puanları ile finansal şirketlerin finansal performansları ilişkisi üzerinde yoğunlaştı̆̆ görülmektedir.

Kayalı ve Doğan (2018), çalışmasında Borsa İstanbul (BİST) Kurumsal Yönetim Endeksinde yer alan imalat sektöründeki işletmelerin 2012-2016 yılları arasında aldıkları kurumsal yönetim derecelendirme notu ile finansal başarıları arasındaki ilişkiyi incelemişlerdir. Çalışma sonucunda işletmelerin kurumsal yönetim derecelendirme notu arttıkça iflas olasılıklarının azaldığı ve dolayısı ile finansal başarılarının arttığı bulgulanmıştır.

Tükenmez v.d. (2017), çalışmasında 2009-2014 dönemi BİST Kurumsal Yönetim Endeksi'nde yer alan mali sektör şirketleri hariç toplam 15 adet işletmenin Kurumsal Yönetim İlkeleri Uyum Derecelendirme puanları (pay sahipleri, menfaat sahipleri, kamuyu aydınlatma ve şeffaflık, yönetim kurulu puanları) ile finansal performansları arasındaki ilişkiyi araştırmıştır. Çalışma sonucunda; işletmelerin kamuyu aydınlatma ve şeffaflık puanları ile aktif karlılıkları arasında anlamlı bir ilişki tespit edilmiş olup; ilişkinin yönü negatif olarak belirlenmiştir. İşletmelerin pay sahipleri ve menfaat sahipleri puanlarının Tobin $Q$ değişkenine etkisi pozitif yönlüdür. Çalışma da kamuyu aydınlatma ve şeffaflık puanları ile Tobin $Q$ değişkeni arasında ise ters yönlü anlamlı bir ilişki tespit edilmiştir.

Karadeniz ve Ergene (2015), çalışmasında halka açık turizm şirketlerinin kurumsal yönetim uygulamalarını incelemek ve halka açık imalat şirketleriyle karşılaştırmayı amaçlamışlardır. Çalışma sonucunda turizm şirketlerinin pay sahipleri ilkelerine, kamuyu aydınlatma ve şeffaflık ilkelerine, yönetim kurullarıyla ilgili ilkelere ve menfaat sahipleriyle ilgili ilkelere uyum açısından imalat şirketlerine göre oldukça fazla eksiklikleri bulunduğu tespit edilmiştir. Ayrıca turizm şirketlerinin kurumsal yönetim ilkelerine uyum sağlama çabası içerisinde olduğu da bulgulanmıştır.

Dizkırıcı v.d. (2015), çalışmasında hesaplanan etkinlik değerleri ile işletmelerin kurumsal yönetim notları karşılaştırılarak aralarında istatistik olarak anlamlı bir ilişkinin olup olmadığını araştırmışlardır. Çalışma sonucunda işletmelerin ilgili döneme ait kurumsal yönetim derecelendirme notları bileşenlerinin; toplam faktör verimliliği ve bileşenlerindeki değişim ile düşük korelasyona sahip olduğu görülmüştür. "Kamuyu Aydınlatma ve Şeffaflık" bileşeninin "Pür Etkinlik Değişimi" ile \% 5 anlamlılık seviyesinde negatif yönlü \% 65,1 oranında korelasyon olduğu diğer ulaşılan sonuçtur.

Ege v.d. (2013), çalışmasında şirketlerin 2009-2011 dönemine ait finansal performansları belirlenmiş ve elde edilen performans sonuçları kurumsal yönetim notları kapsamında değerlendirilerek analiz etmiştir. Çalışma sonucunda, şirketlerin finansal performanslarına göre belirlenen sıralamaları ile kurumsal yönetim notları esas alınarak oluşturulan endeks sıralamalarının aynı yönde hareket etmediği tespit edilmiştir. Şirketlerin finansal performanslarının kurumsal yönetim notları ile pozitif yönde hareket etmediği ve şirketlerin kurumsal yönetim kalitelerinin finansal performanslarına tam olarak yansımadığı tespit edilen diğer bir sonuçtur. 
Conkar v.d. (2011), çalışmasında TOPSís yöntemi ile Endekste yer alan firmaların finansal performansını ölçmek ve derecelendirme kuruluşları tarafından kendilerine verilen kurumsal yönetim notu sıralaması ile karşılaştırmak amaç edinilmiştir. Çalışma soncunda şirketler sıralamaya tabi tutulmuştur.

Karamustafa v.d. (2009), çalışmasında Türkiye'de Ağustos 2008 itibari ile hesaplanmaya başlanan kurumsal yönetim endeksinde işlem gören firmaların, endeks kapsamına girmeden önceki dönemlere göre faaliyet ve finansal performanslarında anlamlı bir değişmenin ortaya çıkıp çıkmadığını araştırmışlardır. Çalışma sonucunda aktif devir hızı, aktif kârlılığ1 ve özsermaye kârlılığ performans göstergelerinde endeks kapsamı öncesi ve sonrası için anlamlı farklılıklar tespit edilmiştir.

Görüldüğü üzere çalışmalar daha çok şirketlerin finansal performansları ile Kurumsal Yönetim Puanları arasındaki ilişki üzerine yoğunlaşmıştır. Bu çalışmada Kurumsal Yönetim Endeksine tabi şirketlerin Kurumsal Yönetim Derecelendirme puanlarının hesaplanmasında, bu puanın oluşumuna etki eden unsurların (Pay Sahipleri, Kamuyu Aydınlatma ve Şeffaflık, Menfaat Sahipleri, Yönetim Kurulu) puana olan etkisini ortaya konulacaktır. Ayrıca derecelendirme şirketine göre puan ortalamaları açısından farklılık olup olmadığını tespit etmek çalışmanın diğer bir amacını oluşturmaktadır.

Çalışmanın bundan sonraki bölümünde araştırma yöntemi ve araştırma bulguları üzerinde durulacaktır.

\section{ARAŞTIRMA}

Çalışmanın bu bölümünde araştırmanın amacı, kapsamı ve sınırlılıkları, yöntemi, üzerinde durulmuş; araştırma bulguları tablolar aracılığı ile kaleme alınmıştır.

\subsection{Araştırmanın Amacı}

Bu çalışmanın amac1; Kurumsal Yönetim Endeksine tabi şirketlerin Kurumsal Yönetim Derecelendirme puanlarının hesaplanmasında, bu puanın oluşumuna etki eden unsurların (Pay Sahipleri, Kamuyu Aydınlatma ve Şeffaflık, Menfaat Sahipleri, Yönetim Kurulu) puana olan etkisini ortaya koymaktır. Ayrıca derecelendirme şirketine göre puan ortalamaları açısından farklılık olup olmadığını tespit etmek çalışmanın diğer bir amacını oluşturmaktadır.

\subsection{Araştırmanın Kapsamı ve Sınırlılıklar}

Borsa İstanbul Kurumsal Yönetim Endeksinde (BIST-XKURY) yer alan; 01.07.2019 tarihi itibari ile 47 adet olan şirketlerin verileri analiz kapsamında incelenecektir. Dönem olarak 2018 yılı belirlenmiştir. 2018 yılı itibari ile ana kitlenin tüm verilerine ulaşılmıştır. Analizi gerçekleştirilen veriler Kurumsal Yönetim Derecelendirme Puanı, Pay Sahipleri Derecelendirme Puanı, Kamuyu Aydınlatma ve Şeffaflık Derecelendirme Puanı, Menfaat Sahipleri Derecelendirme Puanı, Yönetim Kurulu Derecelendirme Puanı olarak 5 sinıfta incelenecektir. Kurumsal Yönetim Derecelendirme Puanı diğer 4 (Pay Sahipleri Derecelendirme Puanı, Kamuyu Aydınlatma ve Şeffaflık Derecelendirme Puanı, Menfaat Sahipleri Derecelendirme Puanı, Yönetim Kurulu Derecelendirme Puanı) puan türünden elde edilmektedir.

\subsection{Araştırmanın Yöntemi}

Araştırma çok değişkenli regresyon analizi yöntemiyle gerçekleştirilmiştir. Çok değişkenli regresyon analizi bir bağımlı değişken ve birden fazla bağımsız değişkenin (yordayıcı değişken) yer aldığı regresyon modelleridir. Bu tür regresyon modellerinde bağımsız değişkenler eş zamanlı olarak bağımlı değişkendeki değişimi açıklamaya çalışmaktadırlar (Coşkun v.d., 2015:239-241). Çok değişkenli regresyon analizi yordayıcı değişkenler tarafından bağımlı değişkende açıklanan toplam varyansın yorumlanmasına, açıklanan varyansın istatistiksel anlamlılı̆̆ına, yordayıcı değişkenlerin istatistiksel olarak anlamlılığına ve yordayıcı değişkenler ile bağımlı değişkenler arasındaki ilişkinin yönüne ilişkin fikir yürütme imkanı vermektedir. Çoklu regresyon analizleri en az aralık ölçeğinde ölçülebilen sürekli değişkenler gerektirir (Büyüköztürk, 2016:98). Çok değişkenli regresyon modeli;

$\mathrm{Y}=\mathrm{a}+\mathrm{b}_{1} \mathrm{X}_{1}+\mathrm{b}_{2} \mathrm{X}_{2}+\ldots \ldots+\mathrm{b}_{\mathrm{n}} \mathrm{X}_{\mathrm{n}}+\mathrm{e}$

şeklinde ifade edilmektedir. Burada $\mathrm{Y}$ bağımlı değişkeni, a sabit katsayıyı, bi bağımsız değişken etki düzeylerini, , $X_{i}$ bağımsız değişkenleri, e ise modeldeki hata terimini temsil etmektedir (Coşkun v.d., 2015:239241). Araştırma kapsamında model ele alındığında; 
Y: Kurumsal Yönetim Puanı

$\mathrm{X}_{1}$ : Pay Sahipleri Derecelendirme Puanı,

$X_{2}$ : Kamuyu Aydınlatma ve Şeffaflık Derecelendirme Puanı,

$\mathrm{X}_{3}$ : Menfaat Sahipleri Derecelendirme Puanı,

$\mathrm{X}_{4}$ : Yönetim Kurulu Derecelendirme Puanı

temsil etmektedir.

O halde araştırma modelini;

Kurumsal Yönetim Puanı $(Y)=a+b 1$. Pay Sahipleri Derecelendirme Puanı + b2. Kamuyu Aydınlatma ve Şeffaflık Derecelendirme Puanı +b3. Menfaat Sahipleri Derecelendirme Puanı+ b4. Yönetim Kurulu Derecelendirme Puanı + e

şeklinde formülleştirmek mümkündür. Çoklu regresyon analizi yapılırken metot olarak " Enter" metodu seçilmiştir. "Enter" metodunda tüm bağımsız değişkenler birlikte analize dahil edilmektedir (Coşkun v.d., 2015:243).

\subsection{Araştırma Bulguları}

Kurumsal Yönetim ve alt boyutlarına ilişkin ortalama ve standart sapma tablosu şöyledir:

Tablo 1. Kurumsal Yönetim Ve Alt Boyutlarına İlişkin Ortalama Ve Standart Sapma

\begin{tabular}{|c|c|c|c|}
\hline Kurumsal Yönetim Alt boyutları & Ort. & S.S. & $\mathbf{N}$ \\
\hline Kurum Notu & 9,3157 & ,29508 & 47 \\
\hline Pay & 9,1794 & ,41600 & 47 \\
\hline Kamuyu Aydınlatma Ve Şeffaflık & 9,4953 & ,35404 & 47 \\
\hline Menfaat Sahipleri & 9,5739 & ,44316 & 47 \\
\hline Yönetim Kurulu & 9,1720 & 29934 & 47 \\
\hline
\end{tabular}

Tanımlayıcı istatistik tablosu incelendiğinde Kurumsal Yönetim Endeksine tabi şirketlerin Kurumsal Yönetim derecelendirme Puanı ortalamaları 9,3757 olarak hesaplanmıştır. Pay Sahipleri Derecelendirme Puanı 9,1794, Kamuyu Aydınlatma ve Şeffaflık Derecelendirme Puanı 9,4953, Menfaat Sahipleri Derecelendirme Puanı 9,5739, ve Yönetim Kurulu Derecelendirme Puanı 9,1720 olarak hesaplanmıştır. Puan ortalaması en yüksek olan unsur Menfaat Sahipleri Puanı iken en düşük olan unsur Yönetim Kurulu Puanı olarak hesaplanmıştır.

Kurumsal Yönetim ve alt boyutlarının birbiri ile olan ilişkisini göstere korelasyon tablosu şöyledir:

Tablo 2. Kurumsal Yönetim Ve Alt Boyutlarına İlişkin Korelasyon

\begin{tabular}{|c|c|c|c|c|c|c|c|}
\hline & & $\begin{array}{c}\text { Kurum } \\
\text { Notu }\end{array}$ & Pay & $\begin{array}{c}\text { Kamuyu } \\
\text { Aydınlatma Ve } \\
\text { Şeffaflık } \\
\end{array}$ & $\begin{array}{l}\text { Menfaat } \\
\text { Sahipleri }\end{array}$ & $\begin{array}{l}\text { Yönetim } \\
\text { Kurulu }\end{array}$ & $\mathbf{p}$ \\
\hline Pearson & Kurum Notu & 1,000 & 759 & ,831 & ,798 & ,860 & \\
\hline \multirow[t]{4}{*}{ Korelasyon } & Pay & ,759 & 1,000 & ,492 & ,392 & 485 & \\
\hline & $\begin{array}{l}\text { Kamuyu } \\
\text { Aydınlatma Ve } \\
\text { Şeffaflık }\end{array}$ & 831 & & 1,000 & ,617 & ,621 & 0,00047 \\
\hline & Menfaat Sahipleri & ,798 & & ,617 & 1,000 & ,696 & \\
\hline & Yönetim Kurulu & ,860 & & 621 & 696 & 1,000 & \\
\hline
\end{tabular}

Korelasyon katsayısı tablosu incelendiğinde Kurumsal Yönetim Puanı ile en yüksek korelasyona sahip olan unsurun Yönetim Kurulu Puanı olduğu görülmektedir. En düşük korelasyon katsayısına sahip unsur ise 
C. Güney 12/2 (2020) 1297-1307

Menfaat Sahipleri Notu dur. Korelasyon katsayıları göz önünde bulundurulduğunda Kurumsal Yönetim Notu ile diğer unsurların pozitif yönde ve yüksek seviyede ilişkili olduğunu söylemek yanlış olmayacaktır.

Araştırma modeline ilişkin özet tablo şöyledir:

Tablo 3. Araştırma Modeli Özeti ${ }^{b}$

\begin{tabular}{lccccc}
\hline Model & R & Kare & $\begin{array}{c}\text { Düzeltilmiş R } \\
\text { Kare }\end{array}$ & $\begin{array}{c}\text { Hesaplanan Std. } \\
\text { Hata }\end{array}$ & $\begin{array}{c}\text { Durbin- } \\
\text { Watson }\end{array}$ \\
\hline $\mathbf{1}$ & $999 \mathrm{a}$ & 999 &, 999 &, 01101 & 2,030 \\
\hline
\end{tabular}

a. Yordayıcılar: (Sabit), Yönetim Kurulu, Pay, Kamuyu Aydınlatma Ve Şeffaflık, Menfaat Sahipleri

b. Bağımlı Değişken: Kurum Notu

Araştırma modelinde açıklanan varyanslar incelendiğinde, modelin unsurlarının Kurumsal Yönetim Puanındaki değişmelerin yüzde 99.9'unu açıkladığı görülmektedir.

Araştırma modeline ilişkin ANOVA analizi sonucu tablosu şöyledir:

Tablo 4. ANOVAa

\begin{tabular}{llcllll}
\hline Model & & Kareler Toplamı & df & Ortalama Kare & F & Sig. \\
\hline 1 & Regresyon & 4,000 & 4 & 1,000 & $8248,481,000^{\mathrm{b}}$ \\
\hline & Kalan & 4005 & 42 &, 000 & \\
\cline { 2 - 6 } & Toplam & 4,005 & 46 & & \\
\hline
\end{tabular}

a. Bağımlı Değişken: Kurum Notu

b. Yordayıcılar: (Sabit), Yönetim Kurulu, Pay, Kamuyu Aydınlatma Ve Şeffaflık, Menfaat Sahipleri

Bu durum ANOVA tablosu ile birlikte değerlendirildiğinde modelin anlamlı olduğu söylenebilir $(\mathrm{p}<0,01)$. Araştırmaya ilişkin regresyon katsayıları tablosu şöyledir:

Tablo 5. Katsayılara

\begin{tabular}{|c|c|c|c|c|c|c|c|c|c|c|}
\hline \multirow[b]{2}{*}{ Model } & \multicolumn{2}{|c|}{$\begin{array}{c}\text { Standardize } \\
\text { Olmayan } \\
\text { Katsayılar }\end{array}$} & \multirow{2}{*}{$\begin{array}{c}\begin{array}{c}\text { Standardize } \\
\text { Katsayılar }\end{array} \\
\text { Beta }\end{array}$} & \multirow[b]{2}{*}{$\mathbf{t}$} & \multicolumn{4}{|c|}{ Korelasyonlar } & \multicolumn{2}{|c|}{ Doğrusal Bağlantı } \\
\hline & B & Std. Hata & & & Sig. & $\begin{array}{l}\text { Sifir- } \\
\text { Sira }\end{array}$ & Kismi & Bölüm & Tolerans & VIF \\
\hline 1 (Sabit) & , 070 & ,053 & & 1,315 &, 196 & & & & & \\
\hline Pay & ,251 & ,005 & ,354 & 54,129 &, 000 & ,759 & ,993 & ,298 & ,706 & 1,417 \\
\hline $\begin{array}{l}\text { Kamuyu } \\
\text { Aydınlatma Ve } \\
\text { Şeffaflık } \\
\end{array}$ & ,251 & ,006 & ,301 & 39,090 & ,000 & ,831 & ,987 & ,215 & ,510 & 1,961 \\
\hline $\begin{array}{l}\text { Menfaat } \\
\text { Sahipleri }\end{array}$ & 160 & ,005 & 241 & 29,698 & 3,000 & 798 & 977 & 163 & ,460 & 2,173 \\
\hline Yönetim Kurulu & ,329 & ,008 & ,334 & 39,877 & 7,000 &, 860 & ,987 & ,219 & ,432 & 2,316 \\
\hline
\end{tabular}

a. Bağımlı Değişken: Kurum Notu

Yordayan değişkenler arsında çoklu doğrusallık probleminin olup olmadığını belirlemek için VIF değeri ve

Tolerans değeri incelenir. Tolerans değeri sıfıra ne kadar yakınsa, çoklu eş doğrusallık problemi o derece 
yüksektir. VIF değerinin ise 2 den büyük olması genellikle bağımlı değişkeni yordayan bağımsız değişkenler arasında çoklu doğrusallık probleminin olduğuna işaret eder (İslamoğlu ve Alnıaçık, 2016:379). Tabloda VIF değerinin 2 ten küçük olduğu, tolerans değerinin ise 1 den küçük olduğu görülmektedir. Ayrıca değişkenler arsındaki korelasyon tablosu incelendiğinde ise bağımsız değişkenler arasında çoklu doğrusallık problemi olmadığını söylemek yanlış olmayacaktır.

Araştırmaya ilişkin çoklu regresyon analizi sonuçları şöyledir:

Tablo 6. Kurumsal Yönetim Puanının Yordamasına İlişkin Standart Çoklu Regresyon Analizi Sonuçları

\begin{tabular}{lccccccc}
\hline Değişken & $\mathbf{B}$ & $\begin{array}{c}\text { Standart } \\
\text { Hata }\end{array}$ & Beta & $\mathbf{T}$ & $\mathbf{P}$ & $\begin{array}{c}\text { Íkili } \\
\mathbf{r}\end{array}$ & $\begin{array}{c}\text { Kismi } \\
\mathbf{R}\end{array}$ \\
\hline Sabit & 0,070 & 0,053 & - & 1,315 &, 196 & & \\
\hline Pay sahipleri & 0,251 & 0,005 & 0,354 & 54,129 & 0,000 & 0,759 & 0,993 \\
\hline Kamuyu Aydinlatma Ve Şeffaflık & 0,251 & 0,006 & 0,301 & 39,090 & 0,000 & 0,831 & 0,987 \\
\hline Menfaat Sahipleri & 0,160 & 0,005 & 0,241 & 29,698 & 0,000 & 0,798 & 0,977 \\
\hline Yönetim Kurulu & $\mathbf{0 , 3 2 9}$ & 0,008 & 0,334 & 39,877 & 0,000 & 0,860 & 0,987 \\
\hline & $\mathbf{R = 0 , 9 9 9}$ & $\mathbf{R}^{2}=\mathbf{0 , 9 9 9}$ & $\mathbf{F ~ ( 4 , 4 2 ) = 8 2 4 8 , 4 8 1}$ & $\mathbf{p = 0 , 0 0 0}$ & & \\
\hline
\end{tabular}

Pay Sahipleri Derecelendirme Puanı, Kamuyu Aydınlatma ve Şeffaflık Derecelendirme Puanı, Menfaat Sahipleri Derecelendirme Puanı, Yönetim Kurulu Derecelendirme Puanı bağımsız değişkenlerine göre Kurumsal Yönetim Puanı bağımlı değişkeninin yordanmasına ilişkin çoklu regresyon analizi sonuçları tablo...'de sunulmuştur. Yordayıcı değişkenler ile bağımlı değişken arasındaki ikili ve kısmi korelasyonlar incelendiğinde Kurumsal Yönetim Puanı ile Yönetim Kurulu Puanı arasında pozitif yönde ve yüksek derecede $(\mathrm{r}=0,860)$ korelasyon olduğu görülmektedir. Kurumsal Yönetim Puanı ile Kamuyu Aydınlatma Ve Şeffaflık Puanı arasında pozitif yönde ve yüksek derecede $(\mathrm{r}=0,831)$ bir korelasyon olduğu görülmektedir. Kurumsal Yönetim Puanı ile Menfaat Sahipleri puanı arasındaki korelasyon katsayısı $(r=0,798)$ olarak hesaplanmıştır. Kurumsal Yönetim Puanı ile Pay sahipleri Puanı arasındaki korelasyon en düşük korelasyon değeri olarak hesaplanmıştır $(\mathrm{r}=0,759)$. Pay Sahipleri Derecelendirme Puanı, Kamuyu Aydınlatma ve Şeffaflık Derecelendirme Puanı, Menfaat Sahipleri Derecelendirme Puanı, Yönetim Kurulu Derecelendirme Puanı Kurumsal Yönetim Puanı ile yüksek düzeyde ve anlamlı bir ilişki olduğunu göstermektedir. (R=0,999 $R 2=$ $0,999 \mathrm{p}<0,01)$. Adı geçen değişken ile birlikte toplam varyansın $0,99^{\prime} \mathrm{u}$ açılanmıştır.

Standardize edilmiş regresyon katsayısına göre (Beta) yordayıcı değişkenlerin Kurumsal Yönetim Puanı üzerindeki göreli önem sırası Pay sahipleri Puanı, Yönetim Kurulu Puanı, Kamuyu Aydınlatma Ve Şeffaflık Puanı, Menfaat Sahipleri Puanı şeklindedir.

Yapılan çok değişkenli regresyon analizine göre Kurumsal Yönetim Puanının yordanmasına ilişkin regresyon eşitliği (matematiksel model) aşağıda şöylece belirtilebilir:

Kurumsal Yönetim Puanı $(Y)=0,070+0,251$. Pay Sahipleri Derecelendirme Puanı +0,251. Kamuyu Aydınlatma ve Şeffaflık Derecelendirme Puanı $+0,160$. Menfaat Sahipleri Derecelendirme Puanı $+0,329$. Yönetim Kurulu Derecelendirme Puanı + 0,01101

Kurumsal Yönetim Derecelendirme Puanı belirlemede her bir ana bölüm için SPK Kurumsal Yönetim İlkeleri'ne paralel olarak aşağıdaki ağırlıklar kullanılmaktadır: (http://www.saharating.com 03.01.2019)

Pay Sahipleri:\%25

Kamuyu Aydınlatma ve Şeffaflık: \%25

Menfaat Sahipleri: \%15

Yönetim Kurulu: \%35 
C. Güney 12/2 (2020) 1297-1307

Analiz sonucunda hesaplanan regresyon denklemi incelendiğinde, değişkenlerin katsayılarının yukarıdaki belirlenen ağırlıklarla paralellik gösterdiği söylenebilir. En fazla sapma Yönetim Kurulu Derecelendirme Puanı'nda hesaplanmıştır.

\section{Derecelendirme Şirketlerine Göre Analiz Sonuçları}

Derecelendirme şirketlerine göre 47 adet Kurumsal Yönetim Endeksinde faaliyet gösteren şirketlerin dağılımı şöyledir:

Tablo 7. Derecelendirme Şirketleri

\section{Derecelendirme Şirketi}

SAHA Kurumsal Yönetim ve Kredi Derecelendirme Hizmetleri A.Ş.

KOBİRATE Uluslararası Kredi Derecelendirme ve Kurumsal Yönetim Hizmetleri A.Ş.

JCR Avrasya Derecelendirme A.Ş

Tablo incelendiğinde en fazla SAHA Kurumsal Yönetim ve Kredi Derecelendirme Hizmetleri A.Ş. şirketi ön plana çıkmaktadır. 2018 yılı itibari ile SAHA derecelendirme şirketinin pazarın yaklaşık olarak \%70'ne hakim olduğu söylenebilir.

Derecelendirme şirketlerinin puanladıkları Kurumsal Yönetim ve alt unsurlarının puan ortalamalarına ilişkin tablo şöyledir:

Tablo 8: Tanımlayıcı İstatistikler

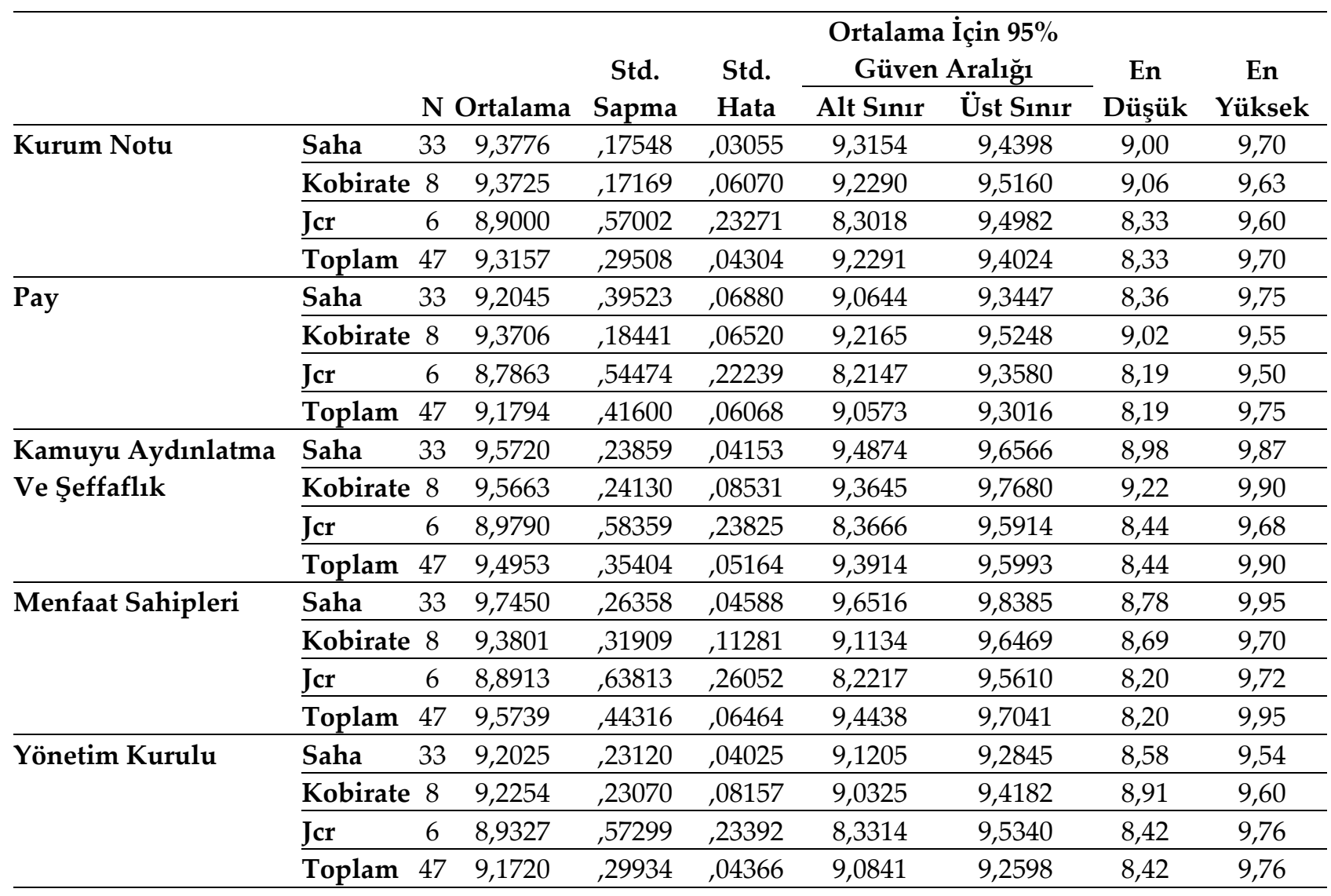

Puan ortalamalarının homojen dağılım gösterip göstermediğine ilişkin tablo ise şöyledir: 
Tablo 9. Varyansların Homojenliği

\begin{tabular}{lccc}
\hline & Levene & & \\
& Istatistiği & df1 df2 Sig. \\
\hline Kurum Notu & 18,011 & 2 & 44,000 \\
\hline Pay & 6,921 & 2 & 44,002 \\
\hline Kamuyu Aydınlatma Ve Şeffaflık & 10,301 & 2 & 44,000 \\
\hline Menfaat Sahipleri & 6,745 & 2 & 44,003 \\
\hline Yönetim Kurulu & 9,110 & 2 & 44,000 \\
\hline
\end{tabular}

Varyansların homojenliği tablosu incelendiğinde anlamlılık değerleri 0,05 den küçük olduğu dolayısıyla homojen dağılım gösterdiği söylenebilir.

Tablo 10. ANOVA

\begin{tabular}{|c|c|c|c|c|c|c|}
\hline & & \multirow{2}{*}{$\begin{array}{c}\text { Kareler } \\
\text { Toplamı }\end{array}$} & \multicolumn{3}{|c|}{ Ortalama } & \multirow[b]{2}{*}{ Sig } \\
\hline & & & df & Kare & $\mathbf{F}$ & \\
\hline \multirow[t]{3}{*}{ Kurum Notu } & Gruplar Arasında & 1,189 & 2 &, 594 & 9,288 & , 000 \\
\hline & Grup İçinde & 2,816 & 44 & ,064 & & \\
\hline & Toplam & 4,005 & 46 & & & \\
\hline \multirow[t]{3}{*}{ Pay } & Gruplar Arasında & 1,240 & 2 & 620 & 4,061 &, 024 \\
\hline & Grup İçinde & 6,720 & 44 & ,153 & & \\
\hline & Toplam & 7,961 & 46 & & & \\
\hline Kamuyu Aydınlatma & Gruplar Arasında & 1,834 & 2 & ,917 & 10,260 & 0,000 \\
\hline \multirow[t]{2}{*}{ Ve Şeffaflık } & Grup İçinde & 3,932 & 44 & ,089 & & \\
\hline & Toplam & 5,766 & 46 & & & \\
\hline \multirow[t]{3}{*}{ Menfaat Sahipleri } & Gruplar Arasında & 4,062 & 2 & 2,031 & 17,975 & 5,000 \\
\hline & Grup İçinde & 4,972 & 44 & ,113 & & \\
\hline & Toplam & 9,034 & 46 & & & \\
\hline \multirow[t]{3}{*}{ Yönetim Kurulu } & Gruplar Arasında & ,397 & 2 & ,199 & 2,346 & , 108 \\
\hline & Grup İçinde & 3,725 & 44 & ,085 & & \\
\hline & Toplam & 4,122 & 46 & & & \\
\hline
\end{tabular}

ANOVA tablosu incelendiğinde ise Yönetim Kurulu puanı dışındaki tüm derecelendirme puanlarının Derecelendirme şirketine göre farklılık göstermediği söylenebilir. Yönetim kurulu puanları incelendiğinde ise JCR şirketine ait derecelendirme puanlarının diğer iki derecelendirme şirketine ait puanlardan anlamlı şekilde farklılaştı̆̆ı görülmektedir ( JCR: 8,9327 SAHA: 9,2025 KOBİRATE: 9,2254).

\section{SONUÇ}

Borsa İstanbul Kurumsal Yönetim Endeksinde (BIST-XKURY) yer alan şirketlerin kurumsal yönetim ilkelerine uyum düzeyi unsurlarının, kurumsal yönetim puanın oluşumundaki etkisini belirlemeyi amaçlayan bu çalışmada ulaşılan temel sonuç; Kurumsal Yönetim İlkeleri unsurların Kurumsal Yönetim puanının oluşumundaki göreli önem sırası Pay sahipleri Puanı, Yönetim Kurulu Puanı, Kamuyu Aydınlatma Ve Şeffaflık Puanı, Menfaat Sahipleri Puanı şeklinde olduğudur. Derecelendirme şirketleri açısından yapılan farklılık analizi sonucuna göre; Yönetim Kurulu puanı dışındaki tüm derecelendirme puanlarının derecelendirme şirketine göre farklılık göstermediği tespit edilmiştir ( JCR: 8,9327 SAHA: 9,2025 KOBIRATE: 9,2254).

Araştırma sonucuna göre; Yönetim Kurulu derecelendirme puanında görülen sapma dışında önem sıralamasının SPK tarafından belirlenen etki düzeylerine paralel olarak şekillendiği söylenebilir. Ayrıca JCR derecelendirme şirketinin Yönetim Kurulu puanlarının diğer iki derecelendirme şirketine ait puanlardan istatistiksel açıdan anlamlı şekilde farklılaştığı da söylenebilir. Literatürde yapılmış çalışmalar daha çok şirketlerin finansal performansları ile Kurumsal Yönetim Puanları arasındaki ilişki üzerine yoğunlaştığı için, bu çalışmada elde edilen sonuçları destekler ya da red eder bir çalışmaya rastlanmamıştır. 


\section{KAYNAKLAR}

Aktan, C.C., Vural, İ.Y. (2007). “Kurumsal Sosyal Sorumluluk: Uluslararası Kuruluşlar ve Hükümet -Dışı Organizasyonlar Tarafından Sürdürülen Başlıca Girişimler". Çimento İşveren Dergisi, 3 (21), 1-21.

Aras, G. (2007). “Kurumsal Sosyal Sorumluluk: Muhasebe ve Denetim Alanına Yansımaları”. Türkiye İç Denetim enstitüsü Dergisi, 20, 24-29.

Büyüköztürk, Ş. (2016). Sosyal Bilimler İçin Veri Analizi El Kitabı. Ankara: Pagem Akademi Yayınları, 22.

Conkar, K., Elitaş, C., Atar, G. (2011). “IMKB Kurumsal Yönetim Endeksi'ndeki (XKURY) Firmaların Finansal Performanslarının Topsis Yöntemi ile Ölçümü ve Kurumsal Yönetim Notu ile Analizi". İstanbul Üniversitesi İktisat Fakültesi Mecmuası, 61(1), 81-115.

Coşkun, R., Altunışık , R., Bayraktaroğlu, S., Yıldırım E. (2015). Sosyal Bilimlerde Araştırma Yöntemi: Spss Uygulamalı. Sakarya: Sakarya Yayıncılık, 8.

Dizkırıcı, A.S., Konuk, F., Topal, B. (2015). “Borsa İstanbul Kurumsal Yönetim Endeksi'nde Yer Alan İmalat İşletmelerinin Etkinlik Değerleri ile Kurumsal Yönetim Notlarının Karşılaştırılması". Finans Politik ve Ekonomik Yorumlar , 52(601), 79-96.

Ege, İ., Topaloğlu, E.E., Özyamanoğlu, M. (2013). “Finansal Performans İle Kurumsal Yönetim Notları Arasındaki İlişki: Bist Üzerine Bir Uygulama". Akademik Araştırmalar ve Çalışmalar Dergisi. 5(9), 100117.

İslamoğlu, H., Alnıaçık, Ü. (2016). Sosyal Bilimlerde Araştırma Yöntemleri-Ibm Spss Uygu-lamalı. İstanbul: Beta Yayınları, 5.

Japan Credit Rating Agency, (2020). Rating Listeleri - Kurumsal Yönetim Derecelendirme http://www.jcrer.com.tr/RatingListCorporateGovernance.aspx ( Erişim Tarihi: 7 Ocak 2020).

Karadeniz, E., Ergene, Ş.B. (2015). “Halka Açık Turizm Şirketlerinde Kurumsal Yönetim Uygulamaları: İmalat Şirketleriyle Karşılaştırmalı Bir Analiz". Seyahat ve Otel İşletmeciliği Dergisi, 12 (2), 73-91.

Karamustafa, O., Varıcı, İ. Er, B. (2009). “Kurumsal Yönetim ve Firma Performansı: İMKB Kurumsal Yönetim Endeksi Kapsamındaki Firmalar Üzerinde Bir Uygulama". Kocaeli Üniversitesi Sosyal Bilimler Enstitüsü Dergisi, (17)1, 100 - 119.

Kayalı, N., Doğan, İ. (2018). “Kurumsal Yönetim Derecelendirme Notu İle İşletmelerin Finansal Başarıları Arasındaki İlişkinin İncelenmesi". Muhasebe ve Finansman Dergisi, 78, 111-124.

Kobirate Anonim Şirketi, (2020). "Kurumsal Yönetim Uyum Derecelendirme Raporları", https://www.kobirate.com.tr/Kurumsal-Yonetim-Uyum-Derecelendirme-Raporlari/ (Erişim Tarihi: 7 Ocak 2020).

Öztürk, M.C. (2014). Kurumsal Sosyal Sorumluluk. Eskişehir: Anadolu Üniversitesi Yayınları.

Saha Kurumsal Yönetim ve Derecelendirme Şirketleri Anonim Şirketi., (2020). Kurumsal Yönetim Derecelendirme Notlarının Anlamı, http://www.saharating.com/ saharati/kurumsal-yonetimderecelendirmesi/kurumsal-yonetim-derecelendirme-notlarinin-anlami/ (Erişim Tarihi: 03Ocak 2020)

Sermaye Piyasası Kurulu (SPK), “Kurumsal Yönetim İlkelerinin Belirlenmesine Ve Uygulanmasına İlişkin Tebliğ". Resmi Gazete, Tarih: 03.01.2014, Sayı : 28871.

Tutar, H. (2013). Konu Anlatıml İşletme ve Yönetim Terimleri Ansiklopedik Sözlük. Ankara: Detay Yayıncllık.

Tükenmez, M., Gençyürek, A. G., Karakelleoğlu, M.İ. (2017). “Kurumsal Yönetim Derecelendirme Notlarının Şirketlerin Finansal Performansı Üzerindeki Etkisi”. Ege Stratejik Araştırmalar Dergisi, 8(1), 1-18.

Türk Dil Kurumu (TDK), (2020). Türk Dil Kurumu Sözlükleri, https://sozluk.gov.tr (Erişim Tarihi: 7 Ocak 2020). 